\title{
Spectrophotometric Determination of Selenium (IV) Using 4,5- diamino-o-xylene as a New Chromogenic Reagent
}

\author{
Mehdi Tavancheh, Asadollah Beiraghi* \\ Department of Analytical Chemistry, Faculty of Chemistry, Kharazmi University, Tehran, Iran
}

\section{A R T I C L E I N F O}

Received: 19 April 2019

Revised: 27 May 2019

Accepted: 24 Jun 2019

Available online: 25 Jun 2019

DOI: $10.33945 /$ SAMI/AJCA.2020.1.3

\section{K E Y W O R D S}

4, 5-Diamino-o-xylene (DAX)

Spectrophotometry

Selenium (IV)

Selenium (VI)

\section{A B S T RACT}

A simple, rapid, and sensitive spectrophotometric method for the determination of selenium (IV) based on the formation of a 1:2 complex with 4,5-diamino- $o$-xylene (DAX) as a new sensitive and selective chromogenic reagent is developed. The DAX reacts with selenium (IV) in the presence of citric acid to form a complex in the $\mathrm{pH}$ range of $1.0 \simeq 2.2$. The experimental conditions for determining selenium including the influences of $\mathrm{pH}$, reagent concentration and time were evaluated and optimized. Under the optimum experimental conditions, the molar absorptivity of the complex was $1.27 \times 10^{4} \mathrm{~L} / \mathrm{mol}^{-1} \mathrm{~cm}^{-1}$ at $340 \mathrm{~nm}$. Beer's law is obeyed in the range of $1 \simeq 12 \mu \mathrm{g} / \mathrm{mL}^{-1}$. The limits of detection and quantization were $0.948 \mu \mathrm{g} \mathrm{mL}-1$ and $3.16 \mu \mathrm{g} / \mathrm{mL}^{-1}$ respectively. The interfering effect of some cations and anions was also studied. This method can be applied to the direct and easy determination of selenium species as organic, inorganic, Se(VI) and Se(IV) in a variety of real samples.

\section{GRA PHICALABSTRACT}

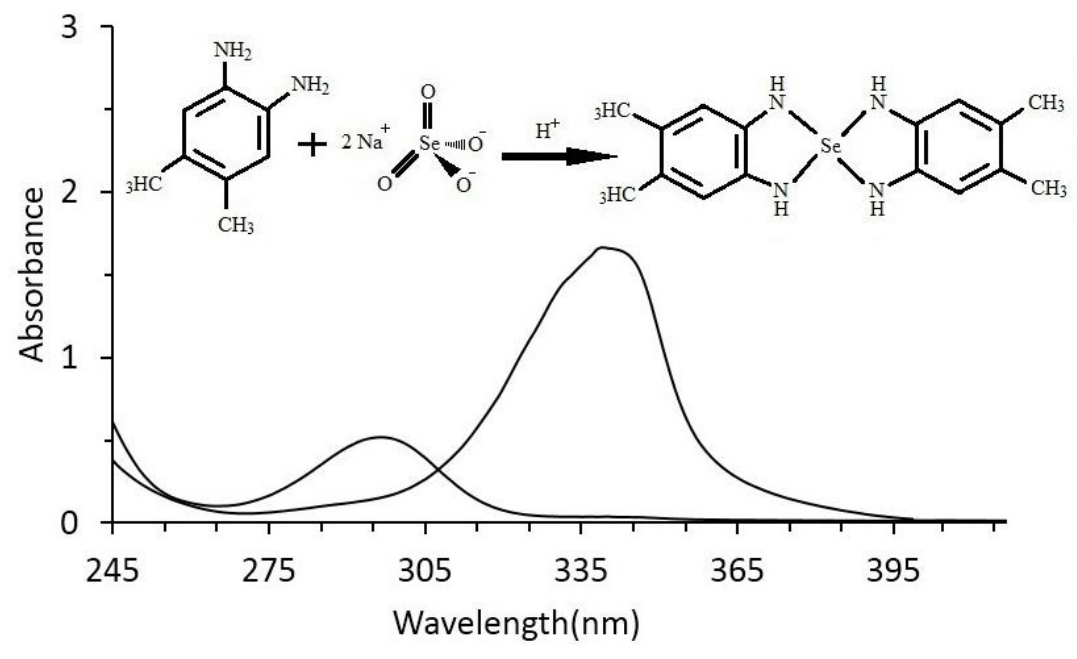

* Corresponding author's E-mail address: beiraghi@khu.ac.ir; beiraghi3061@yahoo.com 


\section{Introduction}

Selenium is a chemical element with the symbol Se and atomic number 34. It is rarely found in elemental form or as pure mineral compounds in the earth's crust. Selenium was discovered in 1817 by J.J. Berzelius (17791848) and J.G. Gahn (1745-1818). Selenium sometimes has metallic properties, and sometimes non-metallic properties, due to its position in the periodic table. Several pharmacological and toxicological properties for selenium have made it a research subject for scientists [1-4]. Currently, a large number of analytical methods upon instrumental techniques have been reported for the determination of selenium (IV), including, HPLC-ICP-MS [5-7], GF-AAS [8], Voltammetry [9-11], GC-MS [12], Instrumental Neutron Activation Analysis, INAA [13], X-ray spectroscopy, X-ray fluorescence spectroscopy [14-15], ICP-OES [16], HG-AFS $[17,18]$, Flow Injection Spectroscopy [19], and other similar techniques. Although these techniques have high sensitivity, they are quite costly for routine analytical use in developing countries and also require skilled laboratory staff and superior laboratory equipment's. Moreover these methods have many individual limitations like use of sophisticated instruments, time consuming operation, requires multi-step procedures for pre-concentration of analyte and low selectivity with higher interference problems. In addition to the above-mentioned methods, studies on molecular spectroscopy-based articles show some drawbacks such as having low molecular absorption coefficients in the ultraviolet region, lack of any report about cationic interferences studies, and in some cases the reported detection limits are not competitive with the results of atomic spectroscopic techniques [20-30].

4,5-diamino-o-xylene (DAX) is a faint yellow powder which is readily soluble in methanol. According to the best of our knowledge, this reagent has not been reported in the literature as being used for determination of selenium. In this study, for the first time, we wish to report this reagent as a selective reagent in spectrophotometric determination of selenium (IV). The high sensitivity and low detection limits of method makes it possible to determine the trace amounts of selenium in the biomass samples.

\section{Experimental}

\section{Materials and chemicals}

All chemicals used were of analytical reagent grade and ultrapure water (Millipore, Direct Q, USA) was used throughout.

Standard selenium (IV) solution (18 $\mathrm{mM}$ ) was prepared by dissolving $0.237 \mathrm{~g}$ of $\mathrm{Na}_{2} \mathrm{SeO}_{3}$ $.5 \mathrm{H}_{2} \mathrm{O}$ (Sigma-Aldrich, USA) in $50.0 \mathrm{~mL}$ ultrapure water, and working standards were prepared by appropriate dilution of the stock solution.

Standard selenium (VI) solution (18 mM) was prepared by dissolving $0.170 \mathrm{~g}$ of $\mathrm{Na}_{2} \mathrm{SeO}_{4}$ (Sigma-Aldrich , USA) in $50.0 \mathrm{~mL}$ water, and working standards were prepared by appropriate dilution of the stock solution.

Chromogenic reagent (18 $\mathrm{mM}$ ) was prepared by dissolving $0.123 \mathrm{~g}$ of 5-diamino-o-xylene (Sigma-Aldrich, USA) in $50.0 \mathrm{~mL}$ methanol, and the other solutions were prepared by appropriate dilution of this solution. Stock solutions were stored in amber glass bottles at $4{ }^{\circ} \mathrm{C}$.

Citric acid solution $(1 \mathrm{M})$ were prepared by dissolving required amount of this acid (merck-millipore, Germany) in ultrapure water.

\section{Instrumentation}

In this study all absorbance measurements were performed with a Shimadzu model UV 1800 double-beam UV-Vis spectrophotometer (Japan). Quarts cells of 1.0 $\mathrm{cm}$ and $50 \mu \mathrm{L}$ were used for all spectral 
measurements. Dragon lab MX-5 vortex mixer was used for mixing of solutions.

General procedure

\section{Se (IV) determination procedure}

An aliquot of $1.0 \mathrm{~mL}$ of a sample solution containing the analyte at concentration ranges $1-50 \mu \mathrm{g} / \mathrm{mL}^{-1}$ was transferred to a volumetric flask (5.0 mL). $0.1 \mathrm{~mL}$ of citric acid solution $(1 \mathrm{M})$ and $1.0 \mathrm{~mL}$ of chromogenic reagent was added, respectively. The mixture was shaken vigorously for 10 seconds and then it was kept in room temperature for $15 \mathrm{~min}$. The absorbance of solution was measured at $340 \mathrm{~nm}$ using a $1.0 \mathrm{~cm}$ quarts cell, against a blank reagent that was prepared in the similar way without selenium (IV).

\section{Results and Discussion}

\section{Spectral data}

\section{Complex formation in acidic condition}

The complex formation reaction of DAX with selenium (IV) was investigated in the

Figure 1. Absorption spectrum of nonacidic DAX (5.0 mL, $0.36 \mathrm{mM})$ and a mixture of non-acidic DAX (5.0 mL, 0.36 $\mathrm{mM}$ ) with added amount of Selenium ion $(25 \mu \mathrm{l}, 7.2 \mathrm{mM})$ present of citric acid ( $0.4 \mathrm{M})$, at ambient temperatures. The absorption spectra were recorded over the wavelength range of 200$400 \mathrm{~nm}$. The resulted spectrums are shown in Figure 1. As it is obvious DAX with selenium (IV) in neutral and alkaline conditions dose not react whereas, in acidic aqueous conditions a water soluble complex is formed (Figure 2). The complex has an absorption band at $340 \mathrm{~nm}$, which was used for the analytical measurements. It is noteworthy that, under the same conditions, DAX does not have any significant absorption band over the investigated wavelength range.

\section{Effect of $p H$ on complex formation}

The $\mathrm{pH}$ of solution plays a unique role on the metal-ligand formation. The effect of this parameter variation on the formation of selenium (IV)-DAX complex was investigated in the $\mathrm{pH}$ range 1.0-3.5 (Figure 3 ). Considering molar absorptivity and quantitative complexation, the method was developed at pH 1.8.

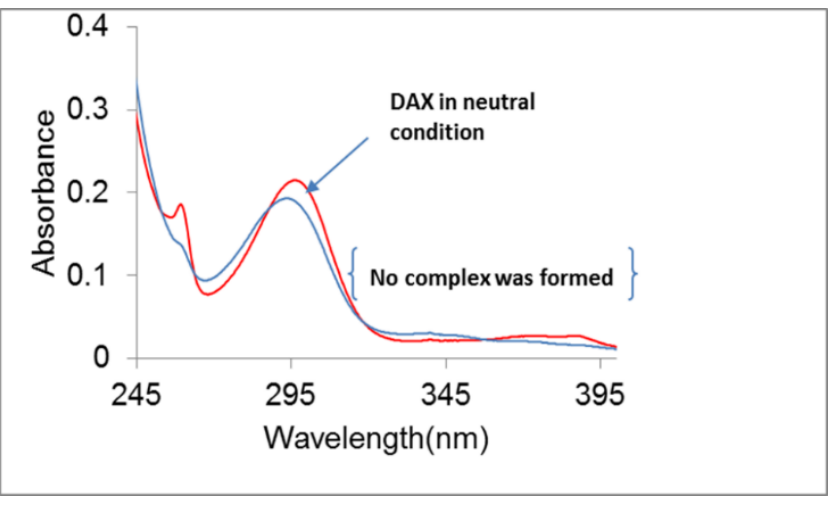

Figure 2. Absorption spectrum of acidic $(0.4 \mathrm{M})$ DAX $(5.0 \mathrm{~mL}, 0.36 \mathrm{mM})$ and a mixture of acidic (0.4 M) DAX (5.0 $\mathrm{mL}, 0.36 \mathrm{mM}$ ) with added amount of Selenium ion $(25 \mu \mathrm{l}, 7.2 \mathrm{mM})$

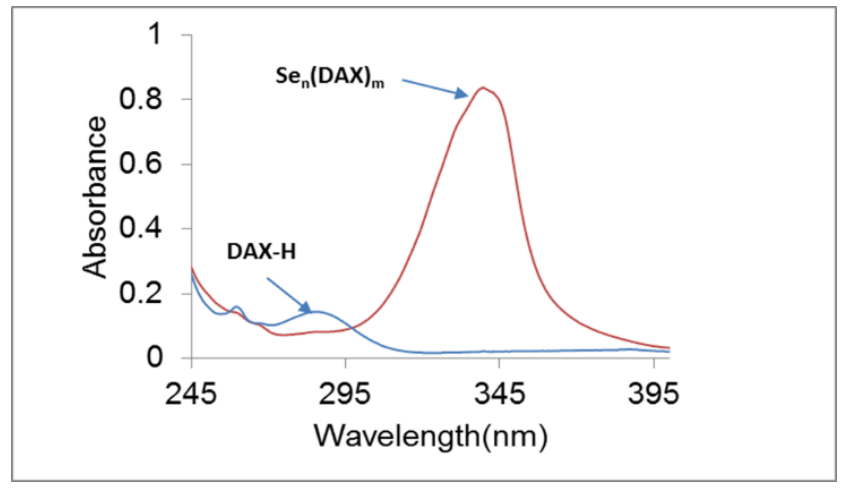




\section{Effect of time}

The effect of time on the stability of selenium-DAX is shown in Figure 3. As seen, maximum absorbance is observed after 15 min at room temperature. The absorbance of complex remained constant for more than $2 \mathrm{~h}$ (Figure 4).

\section{Effect of foreign species}

To study the selectivity of the proposed method, the effect of common ions on the determination of selenium (IV) was tested under the optimum conditions. The tolerance limits of the investigated foreign species are listed in Table 1. As seen, selenium (IV) can be determined without any interference (by spiking Se (IV) at two different concentration levels, an absorption peak appears in $340 \mathrm{~nm}$ (Figure 6) which is proportional to its concentration. Another point that was investigated in this study was the effect of Se (VI) concentration, as an interfering element, on the complexation reaction of Se (IV). As seen in Figure 5, it was found that ligand (DAX) does not react with even higher molar excess of Se (VI), since, there was no absorption band at $340 \mathrm{~nm}$. Instead it was observed that by spiking Se (IV) at two different concentration levels, an absorption band appears in the $340 \mathrm{~nm}$ which is proportional to its concentration (Figure 6).

Figure 3. Effect of $\mathrm{pH}$ on absorbance of Se (IV)-DAX complex at $340 \mathrm{~nm}$

Figure 4. Effect of time on complex absorbance at 340 nm, Conditions: Se (IV), $1.8 \times 10^{-4} \mathrm{mM}$; DAX, $3.6 \times 10^{-2}$ $\mathrm{mM}$; citric acid, $8 \times 10^{-2} \mathrm{mM}$ and room temperature

Figure 5. Se (VI) does not interfere at $340 \mathrm{~nm}$, even when its concentration is high, conditions: acidic Se (VI), $1.8 \times 10^{-2} \mathrm{mM}$; DAX, $3.6 \times 10^{-2} \mathrm{mM}$
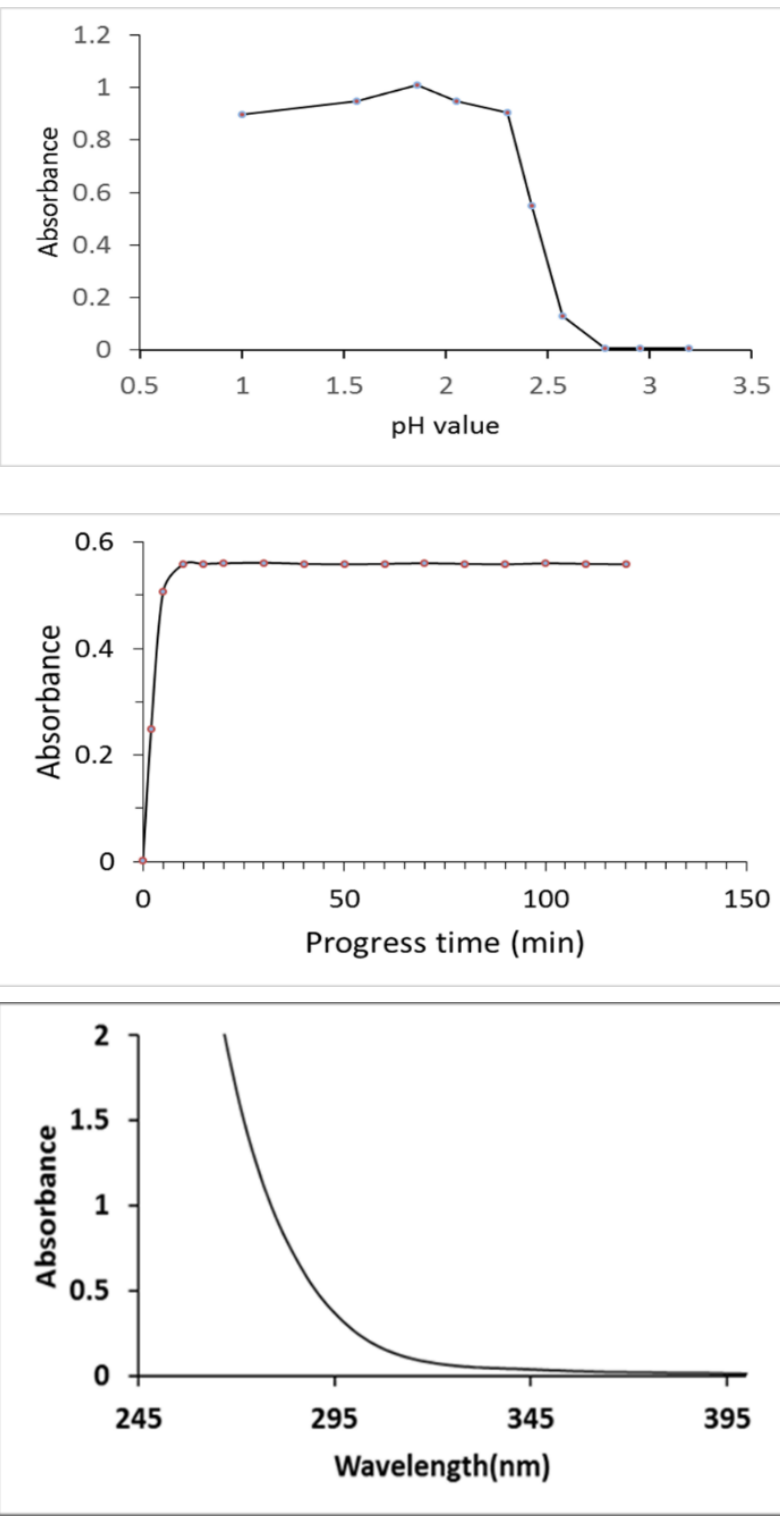
Table 1. Tolerance limits of diverse ions on the selenium (IV) determination

$\begin{array}{cc}\text { Ion added } & \text { Tolerance (ppm) } \\ \mathrm{Cd}(\mathrm{II}), \mathrm{Pb}(\mathrm{II}) & 0.5 \\ \mathrm{Se}(\mathrm{VI}) & 30 \\ \mathrm{Cu}(\mathrm{II}) & 300 \\ \mathrm{Ni}(\mathrm{III}) & 20 \\ \mathrm{Ag}(\mathrm{I}) & 10 \\ \mathrm{Li}(\mathrm{I}), \mathrm{Na}(\mathrm{I}), \mathrm{K}(\mathrm{I}) & 300 \\ \mathrm{Ca}(\mathrm{II}), \mathrm{Mg}(\mathrm{II}), \mathrm{Ba}(\mathrm{II}), \mathrm{Sr}(\mathrm{II}) & 50 \\ \mathrm{Al}(\mathrm{III}), \mathrm{B}(\mathrm{III}) & 1 \\ \mathrm{Cr}(\mathrm{II}), \mathrm{Co}(\mathrm{II}), \mathrm{Fe}(\mathrm{II}), \mathrm{Mn}(\mathrm{IIV}), \mathrm{Zn}(\mathrm{II})_{\mathrm{Gr}}(\mathrm{III}), \mathrm{In}(\mathrm{III}), \mathrm{Tl}(\mathrm{III}) & 0.5 \\ \mathrm{Bi}(\mathrm{III}) & 0.1 \\ \mathrm{PO}_{4}{ }^{3-}, \mathrm{SO}_{4}{ }^{2-}, \mathrm{C}_{2} \mathrm{H}_{3} \mathrm{O}_{2}-\mathrm{NO}_{3}^{-} & 500\end{array}$

Figure 6. By spiking Se (IV) at two different concentration levels, an absorption band appears in the $340 \mathrm{~nm}$ which is proportional to its concentration

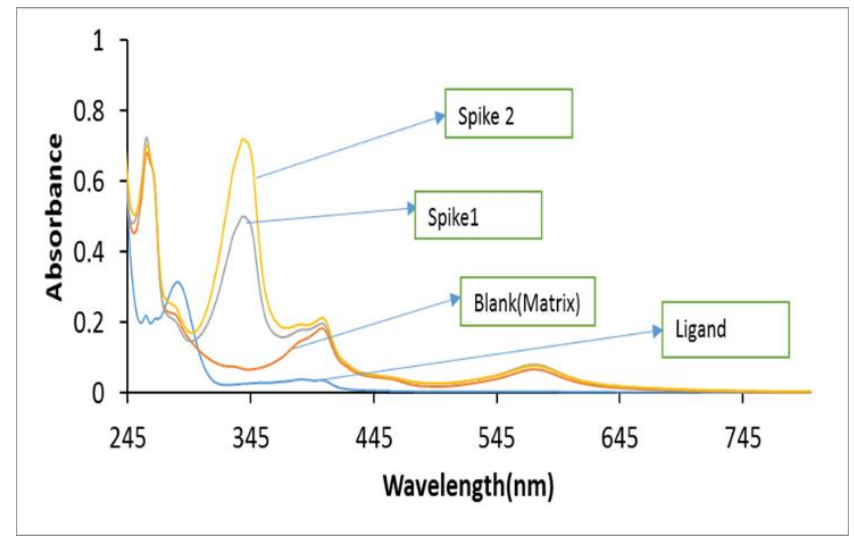

Composition and stability constant of the complex

The stoichiometry of Se (IV)-DAX complex was determined to be 1:2 using both continuous variation (or Job's) method (Figure 7) and molar-ratio method (Figure 8).

\section{Complex formation constant calculation}

For the case of a one-step $\mathrm{ML}_{2}$ complex formation, the following equation could be derived using the ligand concentration

$$
M+2 L \leftrightarrow M L_{2}
$$

$$
\begin{aligned}
& K_{f}=\left[M L_{2}\right] /[L]^{2}[M] \\
& C_{L}=[L]+2\left[M L_{2}\right] \\
& C_{M}=\left[M^{n+}\right]+\left[M L_{2}\right] \\
& K_{f}[L]^{3}+\left(2 C_{M}-C_{L}\right) K_{f}[L]^{2}+[L]+C_{L}=0
\end{aligned}
$$

The corresponding equation used in this study for Job's method is as follows

$K_{f}=\frac{[M L]}{[M] \times[L]}$

$K f=\frac{\left[\frac{A_{2}}{A_{1}}\right]}{\left[1-\left(\frac{A_{2}}{A_{1}}\right)\right] \times\left[C_{L}-C_{M} \times\left(\frac{A_{2}}{A_{1}}\right)\right]}$

Where, $A_{1}=$ absorbance at break point, $A_{2}=$ 
actual absorbance, $\mathrm{C}_{\mathrm{M}}=$ concentration of metal $(\mathrm{M})$, and $\mathrm{C}_{\mathrm{L}}=$ concentration of ligand (M). Based on these calculations, the constant formation for this complex is equal to $1.84 \times 10^{5}$.

\section{Analytical characteristics}

In the proposed method, the calibration graph (Figure 9) obeys the equation $\mathrm{A}=0.188 \mathrm{C}\left(\mu \mathrm{g} / \mathrm{mL}^{-1}\right)-3.2 \times 10^{-5}$, which has a good regression coefficient $(r=0.9991)$

Figure 7. Job's method for stoichiometry determination of the complex at $340 \mathrm{~nm}$

Figure 8. Mole-ratio method for stoichiometry determination of the complex at $340 \mathrm{~nm}$, Conditions: Se (IV) concentration $\left(3.6 \times 10^{-5} \mathrm{M}\right)$ and DAX concentration was varied from $1.8 \times 10-5-$ $1.8 \times 10^{-4}$. over a wide concentration range 1-12 $\mu \mathrm{g} / \mathrm{mL}^{-1}$.

The molar absorptivity was calculated to be $1.27 \times 10^{4} \mathrm{~L} / \mathrm{mol}^{-1} \mathrm{~cm}^{-1}$ at $340 \mathrm{~nm}$, The limits of detection and quantification for selenium (IV) were found to be LOD $=3 \times \mathrm{S}$ $+b$ (where, $S$ is standard error of calibration plot and $\mathrm{b}$ is blank signal) and $\mathrm{LOQ}=10 \times \mathrm{S}$ $+\mathrm{b}$ are $0.948 \mu \mathrm{g} / \mathrm{mL}^{-1}$ and $3.16 \mu \mathrm{g} / \mathrm{mL}^{-1}$ respectively. Analytical characteristics of Se (IV) - DAX complex are given in Table 2 .
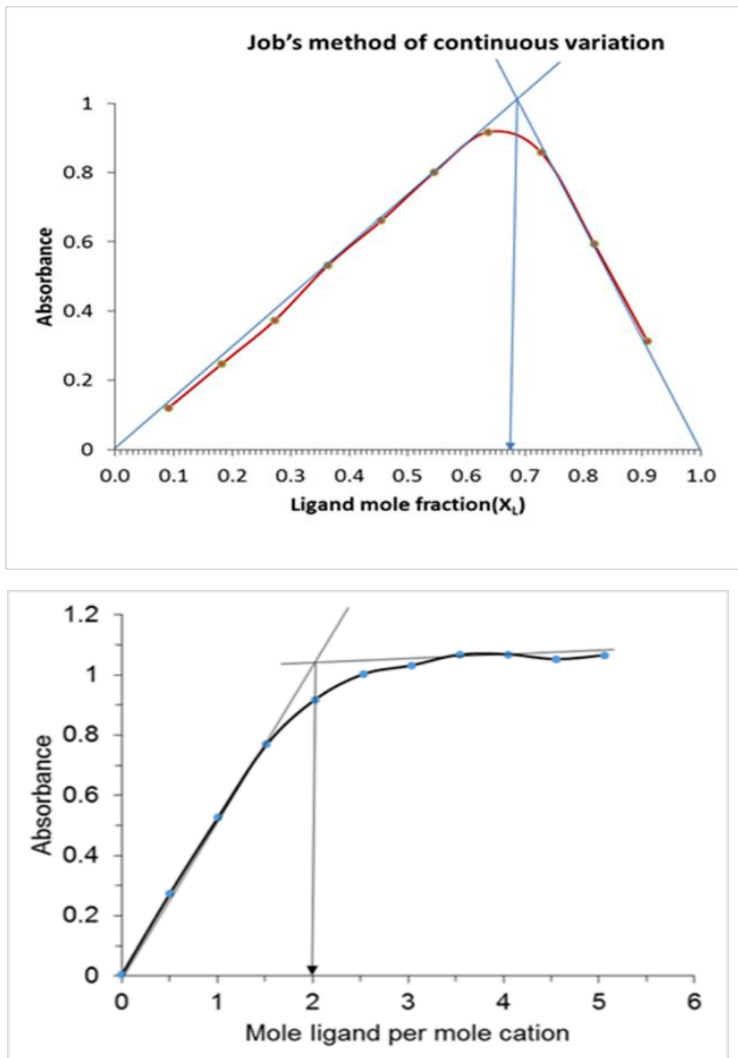

Table 2. Analytical characteristics of the proposed method

\begin{tabular}{cc} 
Parameters & Optimum range \\
Reaction Medium & acidified sample matrix \\
$\lambda$ max & $340 \mathrm{~nm}$ \\
Beer's law range & $1 \simeq 12 \mu \mathrm{g} / \mathrm{mL}^{-1}$ \\
Molar absorptivity $\left(\mathrm{L} / \mathrm{mol}^{-1} \mathrm{~cm}^{-1}\right)$ & $1.27 \times 104$ \\
Sandell,s Sensitivity $\left(\mu \mathrm{g} / \mathrm{cm}^{-2}\right)$ & 0.276 \\
Stoichiometry $(\mathrm{M}: \mathrm{L})$ & $1: 2$ \\
Limit of Detection $\left(\mu \mathrm{g} / \mathrm{mL}^{-1}\right)$ & 0.948 \\
Limit of Quantitation $\left(\mu \mathrm{g} / \mathrm{mL}^{-1}\right)$ & 3.16 \\
Standard error of calibration curve & 0.021 \\
Slope & 0.188 \\
R Square & 0.9991 \\
\hline
\end{tabular}


Table 3. Comparison of some spectroscopic methods for Se (IV) detection

\begin{tabular}{|c|c|c|c|c|c|}
\hline Material Reagent & $\begin{array}{c}\lambda_{\max } \\
(\mathrm{nm})\end{array}$ & Complex formation condition & $\begin{array}{c}\text { Molar } \\
\text { Absorptivity } \\
(\varepsilon)\end{array}$ & Remark & Ref. \\
\hline $\begin{array}{l}\text { 4-( } 4^{\prime} \text { - } \\
\text { Chlorobenzyliden } \\
\text { eimino })-3 \text {-methyl- } \\
\text { 5-mercapto-1,2, } 4 \text { - } \\
\text { triazole(CBIMMT) }\end{array}$ & 470 & $\begin{array}{c}\text { to sample solution, } \\
\text { chromogenic reagent in } \\
\text { organic solvent was added }\end{array}$ & $0.3341 \times 10^{4}$ & $\begin{array}{l}\text { Liquid - Liquid } \\
\text { Extraction }\end{array}$ & [23] \\
\hline $\begin{array}{l}\text { O-methoxyphenyl } \\
\text { thiourea }\end{array}$ & 350 & $\begin{array}{l}\text { Test solution was equilibrated } \\
\text { with OMePT in chloroform for } \\
3 \mathrm{~min}\end{array}$ & $3.312 \times 10^{2}$ & $\begin{array}{l}\text { Liquid - Liquid } \\
\text { Extraction, } \\
\text { Low molar } \\
\text { absorptivity }\end{array}$ & [29] \\
\hline $\begin{array}{l}\text { in-direct } \\
\text { cetyltrimethylam } \\
\text { monium cation } \\
\text { and iodide }\end{array}$ & 360 & $\begin{array}{l}\text { An aliquot of the sample } \\
\text { was transferred into a } 25 \mathrm{~mL} \\
\text { sample vial, then } 2 \mathrm{~mL} \text { sodium } \\
\text { iodide solution was added and } \\
\text { the solution was mixed until } \\
\text { a yellow color was appeared }\end{array}$ & $\ldots \ldots \ldots \ldots \ldots$ & In-direct & {$[20]$} \\
\hline $\begin{array}{c}4,4^{\prime}- \\
\text { dichlorodithizone }\end{array}$ & 416 & $\begin{array}{c}\text { The test solution } \\
\text { was extracted twice with } 10 \\
\text { mL of } n \text {-hexane containing the } \\
\text { reagent } \\
\text { by shaking for } 2 \text { min }\end{array}$ & $9 \times 10^{4}$ & $\begin{array}{l}\text { Liquid - Liquid } \\
\text { Extraction }\end{array}$ & {$[28]$} \\
\hline $\begin{array}{l}\text { 5,6-diaminouracil } \\
\text { hydrochloride } \\
\text { (DAUH) }\end{array}$ & 343 & $\begin{array}{l}\text { To the the test solution, } \\
\text { Hydrochloric acid and DAUH } \\
\text { Were added. The absorbance } \\
\text { of the solution was measured } \\
\text { after about } 30 \text { minutes }\end{array}$ & $0.5 \times 10^{4}$ & $\begin{array}{l}\text { time } \\
\text { consuming }\end{array}$ & {$[30]$} \\
\hline $\begin{array}{l}\text { N-1-naphthyl- } \\
\text { ethylenediamine } \\
\text { dihydrochloride } \\
\text { (NEDA) }\end{array}$ & 545 & $\begin{array}{c}\text { two-step azo coupling reaction } \\
\text { of amines }\end{array}$ & $2.85 \times 10^{4}$ & $\begin{array}{l}\text { time } \\
\text { consuming, } \\
\text { Heating, } \\
\text { Multi-stage }\end{array}$ & {$[27]$} \\
\hline $\begin{array}{l}\text { 4,5-Diamino-6- } \\
\text { hydroxy-2- } \\
\text { mercapto } \\
\text { pyrimidine } \\
\text { (DAHMP) }\end{array}$ & 458 & $\begin{array}{c}\text { sample, } \\
\text { Citric Acid, and DAHMP. } \\
\text { Samples were allowed to } \\
\text { stand for } 10 \text { minutes in order } \\
\text { to complete reaction }\end{array}$ & 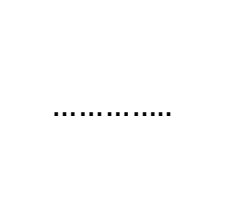 & $\begin{array}{l}\text { separation } \\
\text { and pre- } \\
\text { concentration } \\
\text { step }\end{array}$ & [26] \\
\hline $\begin{array}{l}\text { Leuco Malachite } \\
\text { Green }\end{array}$ & 615 & $\begin{array}{l}\text { Oxidation of leuco malachite } \\
\text { green to malachite green dye } \\
\text { for subsequent } \\
\text { spectrophotometric } \\
\text { measurement }\end{array}$ & $1.67 \times 10^{5}$ & $\begin{array}{l}\text { time } \\
\text { consuming, } \\
\text { Heating, } \\
\text { Multi-stage }\end{array}$ & [22] \\
\hline $\begin{array}{l}\text { 4, 5-Diamino-o- } \\
\text { xylene (DAX) }\end{array}$ & 340 & $\begin{array}{c}0.1 \mathrm{~mL} \text { of } 1 \mathrm{M} \text { citric acid } \\
\text { solution and } 1.0 \mathrm{~mL} \text { of } \\
\text { chromogenic reagent were } \\
\text { added to the test solution and } \\
\text { was kept for } 15 \mathrm{~min} \text { to } \\
\text { complete complex formation } \\
\text { reaction. }\end{array}$ & $1.27 \times 10^{4}$ & $\begin{array}{l}\text { Simple, Rapid, } \\
\text { Sensitive, } \\
\text { Specific }\end{array}$ & $\begin{array}{l}\text { New } \\
\text { Rea- } \\
\text { gent }\end{array}$ \\
\hline
\end{tabular}


Figure 9. Calibration curve

\section{Conclusion}

Spectrophotometric studies on DAX showed that it forms a selective and stable complex with Se (IV) having a M:L ratio of $1: 2$ and $\log \mathrm{K}_{\mathrm{f}}=1.84 \times 10^{5}$. This is the first time this reagent is being used for the determination of Se (IV). The proposed method can be used for selective and specific determination of Se (IV) in the presence of other foreign cations without using any masking agents. Also Se (VI) does not interfere, even when its concentration is high. As shown in Table 3, what makes this reagent different from others that used in selenium spectrometric studies is the rapid and simple reaction of forming a stable complex with high molar adsorption coefficient and the lack of multiple parameters that influence the analytical signal. Due to the solubility of formed complex in the aqueous phase, it is possible to develop methods for identifying and determining trace amount of selenium species.

\section{Acknowledgments}

The authors are thankful to the managements of zistakhmir supplements Co. laboratories because of technical support.

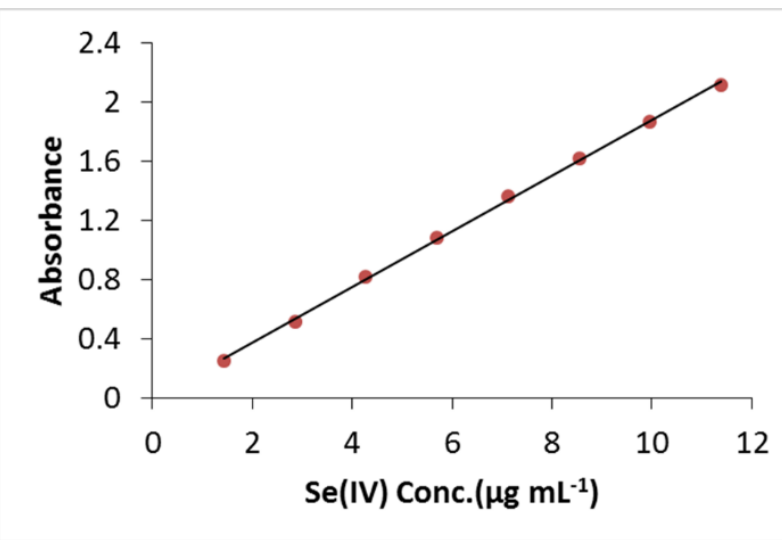

\section{References}

[1]. J.E. Spallholz, Free Radic. Biol. Med., 1994, 17, 45-64.

[2]. C.W. Nogueira, J.B. Rocha, Arch. Toxicol., 2011, 85, 1313-1359.

[3]. G.N. Schrauzer, J. Nutr., 2000, 130, 16531656.

[4]. M. Ponce, I. Giraldez, S. Calero, P. RuizAzcona, E. Morales, C. Fernández-Díaz, I. Hachero-Cruzado, Aquaculture, 2018, 484,105-111.

[5]. J. Moreda-Piñeiro, J. Sánchez-Piñero, A. Mañana-López, I. Turnes-Carou, E. AlonsoRodríguez, P. López-Mahía, S. MuniateguiLorenzo, Food Res, Int., 2018, 111, 621-630. [6]. M. Bueno, F. Pannier, M. Potin-Gautier, J. Darrouzes, Agilent Tech. Int., 2007, 2007, 15.

[7] M.A. Bryszewska, A. Måge, J. Trace Element. Med. Biol., 2015, 29, 91-98.

[8]. T. Pérez-Corona, Y. Madrid, and C. Cámara, Anal. Chim. Acta, 1997, 345, 249255.

[9]. P. Devi, R. Jain, A. Thakur, M. Kumar, N.K. Labhsetwar, M. Nayak, P. Kumar, TrAC Trend. Anal. Chem., 2017, 95, 69-85.

[10]. M. Panigati, L. Falciola, P. Mussini, G. Beretta, R.M. Facino, Food Chem., 2007, 105, 1091-1098.

[11]. M. Ochab, I. Gęca, M. Korolczuk, Talanta, 2017, 165, 364-368.

[12]. X. Zhang, L. Yang, Z. Mester, Anal. Chim. 
Acta, 2012, 744, 54-59.

[13]. I.J. Kim, R.P. Watson, R.M. Lindstrom, Anal. Chem., 2011, 83, 3493-3498.

[14]. H. Stosnach, Spectrochim. Acta - Part B Atomic Spectroscopy, 2010, 65, 859-863.

[15]. Natalia V. Dolgova, Susan Nehzati, Sanjukta Choudhury, Tracy C. MacDonald, Nathan R. Regnier, Andrew M. Crawford, Olena Ponomarenko, Graham N. George, Ingrid J. Pickering, Biochim. Biophys. Acta (BBA)-General Subject., 2018, 1862, 23832392.

[16]. S. Recknagel, P. Brätter, A. Tomiak, U. Rösick, Fresenius j. anal. Chem., 1993, 346, 833-836.

[17]. A. Shishov, M. Wieczorek, P. Kościelniak, D. Dudek-Adamska, A. Telk, L. Moskvin, A. Bulatov. Talanta, 2018, 181, 359-365.

[18]. D.L.F. Silva, M.A.P. Costa, L.O.B. Silva, W.N.L. Santos, Food Chem., 2019, 273, 24-30. [19]. K.S. Kumar, K. Suvardhan, S.H. Kang, J. Pharm. Sci., 2008, 97, 1927-1933.

[20]. A.M.H. Shabani, S. Dadfarnia, M. Nozohor, Spectrochim. Acta A, 2013, 116, 15.

[21]. A.P. Mörschbächer, A. Dullius, C.H. Dullius, C.R. Bandt, D. Kuhn, D.T. Brietzke, F.J.M. Kuffel, H.P. Etgeton, T. Altmayer, T.E. Gonçalves, E.Q. Oreste, Food chem., 2018, 255, 182-186.

[22]. H.D. Revanasiddappa, B.P. Dayananda, Central Eur. J. Chem., 2006, 4, 592-603.

[23]. U.B. Barachea, A.B. Shaikha, T.N. Lokhandea, M.A. Anuseb, G.S. Kambleb, V.M. Guramea, S.H. Gaikwad, J. Environ. Chem. Eng., 2017, 5, 4828-4840.

[24]. X. Wen, Y. Zhang, C. Li, X. Fang, and X. Zhang, Spectrochim. Acta-Part A: Mol. Biomol. Spectrosc., 2014, 123, 200-205.

[25]. M.H. Soruraddin, R. Heydari, M. Puladvand, M.M. Zahedi, Int. J. Anal. Chem., 2011, Article ID 729651, 8 pages.

[26]. H.I. Ulusoy, Anal. Method., 2015, 7, 953-960.

[27]. A. Matamoros-Veloza, L.G. Benning,
Mineralog. Mag., 2008, 72, 451-454.

[28]. M.S. El-Saeed El-Shahawi, A.M. Othman, A.S. Bashammakh, M.A. El-Magied ElSonbati, Int. J. Environ. Anal. Chem., 2006, 86, 941-954.

[29]. S.H. Han, R.M. Naval, S.R. Kuchekar, Int. J. Environ. Anal. Chem., 2015, 95, 618-634. [30]. S.F. Raasi, Int. Lett. Chem., Phys. Astron., 2015, 61, 126.

How to cite this manuscript: Mehdi Tavancheh, Asadollah Beiraghi, Spectrophotometric Determination of Selenium (IV) Using 4,5-diamino-oxylene as a New Chromogenic Reagent, Adv. J. Chem. A, 2020, 3(1), 15-23. 